\title{
Unilateral Frontal Interhemispheric Transfalcial Approaches for the Removal of Olfactory Groove Meninjiomas
}

\section{Olfaktör Oluk Menengiomlarnm Çıkarılmasinda Tek Yanlı Frontal Interhemisferik Transfalsian Yaklaşımm Sonuçları}

\author{
Ahmet Murat MUSLUMAN ${ }^{1}$, Adem YILMAZ ${ }^{1}$, Tufan CANSEVER ${ }^{2}$, Halit CAVUSOGLU ${ }^{1}$, \\ Okan KAHYAOGLU ${ }^{1}$, Yunus AYDIN ${ }^{1}$ \\ ${ }_{1}^{1}$ Sisli Etfal Research and Education Hospital, Department of Neurosurgery, Istanbul, Turkey \\ ${ }^{2}$ Baskent University, Istanbul Hospital, Department of Neurosurgery, Istanbul, Turkey
}

Correspondence address: Ahmet Murat MUSLUMAN / E-mail: mmusluman@yahoo.com

\begin{abstract}
AIM: A unilateral subfrontal interhemispheric transfalcial approach for the removal of olfactory groove meningiomas (OGM) was evaluated in terms of surgical technique, complications, clinical outcomes, and recurrence rate.

MATERIAL and METHODS: Twenty-four females and eighteen males with a mean age of 59 years were operated on for OGM within a 12year (1996-2008) period. The pre- and post-operative Mini-Mental Test (MMT) scores, visual impairment scores (VIS), pre-operative clinical symptoms (headache, epileptic seizure and anosmia), Karnofsky performance scores (KPS), tumor size and tumor extensions were evaluated. The effects of the pre-operative parameters on post-operative MMT, VIS and KPS were investigated.

RESULTS: Tumor size and pre-operative MMT significantly affected pre-operative KPS. Mean tumor diameter was $5.6 \pm 0.8 \mathrm{~cm}$. Total excision was achieved in $97.6 \%$ of all cases. No peri-operative mortality was seen. Ten patients (23.8\%) experienced surgery-related complications. The mean follow-up period of cases was 52 months, and the rate of residual tumor re-growth was $2.3 \%$. No parameter showed any effect on post-operative KPS, as no significant difference was seen between pre- and post-operative KPS. A significant positive difference was detected between pre- and post-operative MMT and VIS.
\end{abstract}

CONCLUSION: A unilateral subfrontal interhemispheric transfalcial approach can be the preferred modality for treating OGM.

KEYWORDS: Olfactory groove meningioma, Unilateral, Surgical approach, Outcome, Recurrence

öz

AMAÇ: Olfaktor oluk meningiomalarının (OOM) çıkarılması için kullandığımız tek taraflı subfrontal interhemisferik transfalsian yaklaşım cerrahi teknik, komplikasyonlar, klinik sonuçlar ve nüks oranı açısından değerlendirildi.

YÖNTEM ve GEREÇLER: 12 yıllık (1996-2008) süre içinde OOM nedeniyle ameliyat edilen hastaların yirmi dört'ü kadın, on sekiz'i erkek ortalama yaş 59.4 \pm 12.4 idi . Pre-ve post-operatif Mini Mental Test (MMT) skorları, görme bozukluğu skoru (VIS), ameliyat öncesi klinik semptomları (baş ağrısı, epileptik nöbet ve anosmi), Karnofsky performans puanları (KPS), tümör boyutu ve tümör büyüme paterni değerlendirildi. Post-operatif MMT üzerinde ameliyat öncesi VIS ve KPS parametrelerin etkileri, araştırıldı.

BULGULAR: Tümör boyutu ve ameliyat öncesi MMT ameliyat öncesi KPS nu anlamlı etkiledi. Ortalama tümör çapı $5.6 \pm 0.8 \mathrm{~cm}$ idi. Total eksizyon olguların \% 97.6 sında sağlandı. Peri-operatif mortalite görülmedi. On hastada (\% 23.8) cerrahiye bağlı istenmeyen durum meydana geldi. Olguların ortalama takip süresi 52 aydı, nüks oranı\% 2.3 idi. Ameliyat öncesi ve sonrası KPS arasında anlamlı bir fark görülmedi. Hiçbir parametre, post-operatif KPS üzerine anlamlı bir etki göstermedi. Anlamlı pozitif fark ameliyat öncesi ve sonrası MMT ve VIS arasında tespit edildi.

SONUÇ: Tek taraflı subfrontal interhemisferik transfalcian yaklaşım OOM tedavisi için tercih edilebilecek yöntem olabilir.

ANAHTAR SÖZCÜKLER: Olfaktör oluk menengiomu, Tek yanlı, Cerrahi yaklaşım, Sonuçlar, Nüks 


\section{INTRODUCTION}

Olfactory groove meningiomas (OGM), which constitute approximately $10 \%$ of all intracranial meningiomas, arise from the cribriform plates and can reach larger sizes before the manifestation of clinical signs $(4,11,27)$. These tumors are located on the base of the frontal fossa. The tumor usually infiltrates the crista galli and posterior planum sphenoidale and grows symmetrically on the midline or tends to grow predominantly on one side. An OGM was first removed by Francesco Durante in 1885 using left frontal craniotomy $(4,5)$. During subsequent years, unilateral frontal, bifrontal, pterional, frontoorbitonasal, orbital osteotomic approaches and their combinations have been used. Recently, small-scale series have been published by various centers on the removal of OGM, but the definite superiority of one surgical technique over others has not been demonstrated. Many surgeons prefer to use bifrontal or unifrontal approaches depending on the size of the tumor $(1,2,18-20,23,27)$.

A modified (transfalcial approach to the opposite side) unilateral approach was used in 42 consecutive patients regardless of tumor size in this study. The pre-operative findings and post-operative results were evaluated.

\section{MATERIAL and METHODS}

This prospective observational study was based on medical records of patients operated in the neurosurgical department of our Hospital. In our clinic 525 cases diagnosed as meningiomas between 1996 and 2008 were operated on; $42(8 \%)$ were OGM. Twenty-four females (57\%) and 18 males $(43 \%)$ with a mean age of $59 \pm 12.4$ years (range $42-72$ years) were enrolled in the study. The duration from the initial symptom to the time of surgical tumor removal ranged from 3 to 61 months.

Based on the pre-operative CT and MRI findings, tumors were classified on the basis of their growing pattern and size. These tumors were stratified according to their largest diameters as group $1(<4 \mathrm{~cm})$, group $2(4-6 \mathrm{~cm})$ and group $3(>6 \mathrm{~cm})$.

\section{Clinical Evaluation}

Headache ( $\mathrm{n}=37,88 \%)$ was the most common symptom leading to further diagnostic work-up. Other preoperative clinical symptoms were mental state alterations $(n=28,66.6 \%)$, visual disorders $(n=23,54.7 \%)$, anosmia $(n=19,45.2 \%)$, and epileptic seizure $(n=10,23.8 \%)$.

\section{Karnofsky performance status and Mini-Mental Test}

The patients' KPS were evaluated pre- and post-operatively (12). The MMT (also known as the Mini-Mental State Examination or Folstein test) is a brief, 30-point questionnaire that is used to screen for cognitive impairment. It is also used to estimate the severity of patients' cognitive impairment and response to treatment (9).

\section{Ophthalmologic tests and evaluation}

In the pre-operative period all patients were evaluated ophthalmologically by the same department. Visual acuity was measured using the Snellen visual acuity test at $5 \mathrm{~m}$ in 200 lux of light. Change in visual acuity was defined as a change of one or more Snellen lines. For visual field analysis, a Humphrey automated visual field device was used. For each patient, VIS was calculated according to the guidelines of the German Ophthalmological Society. This score was originally applied by Fahlbusch and Schott (8) to analyze the visual status and the surgical outcome of tuberculum sellae and planum sphenoidale meningioma patients. VIS is obtained by adding the scores in specific tables concerning visual acuity and visual field defect, respectively. The score ranges from 0 (best) to 100 (worst).

The same evaluations were repeated at the third and sixth post-operative months, and the benefits provided from the operation were statistically assessed.

\section{Surgical Procedure}

The operation was performed in a similar fashion to a unilateral frontal approach that has been previously known, with some modifications. Detailed description of the surgical technique was shown in Figure $1 \mathrm{~A}-\mathrm{l}$. The right anterior basal tumoral nutrient arteries were cauterized, and after partial removal of the tumor in anteroposterior direction. Afterwards, all nutrient arteries of the tumor inside the olfactory groove and all insertion sites were dissected away. Any attachment between the inferoposterior aspect of the tumor and optic nerve and the carotid artery was dissected. Then, the superior portion of the tumor was dissected away from the adjacent right and left frontal lobe, and particular attention was paid to the dissection of the posterior pole of the tumor to free it from the A-2 segment of the anterior cerebral arteries (ACA) and pericallosal arteries. The resection of the tumor was then completed. The cribriform plate was cauterized and drilled basally according to the presence or absence of invasion into dura and bone tissue at its insertion site (Figure 2). According to the size of the bone defect at the base of the tumor, reconstruction with pericranial flap and fibrin glue was performed. After closure of dura, any debris on the mucosa of the frontal sinus was removed, and the sinus was filled with pedicled pericranial flap (Figure $3 A, B ; 4 A, B$ ).

\section{Follow-Up Examinations}

Patients were followed up regularly at intervals of $1,3,6$, and 12 months. All patients were also followed-up with MRI in the $6^{\text {th }}$ and $12^{\text {th }}$ months after surgery. Thereafter, patients were reexamined at 1-year intervals based on each follow-up result.

\section{Statistical Analysis}

Statistical calculations were performed with SPSS 16.0 for Windows. Besides standard descriptive statistical calculations (mean, standard deviation, frequency), Wilcoxon signedrank test was utilized to compare the headache, seizure and anosmia groups and the subgroups of the tumor sizes. A linear regression test was used to evaluate the effects of sex, age, symptoms, and tumor size and extension on the pre- and post-operative VIS, KPS and MMT and their effects 




Figure 1: A unilateral temporofrontal coronal scalp skin incision was made starting from the tragus (A). Unilateral frontal craniotomy, generally measuring $5 \times 6 \mathrm{~cm}$, was performed through two burr holes on the sagittal sinus over the orbital rim at the midline and two burr holes on the temporal line (B). A U-shaped dissection was made on the dura, with its base within the sagittal sinus (C, D). At the start of the subfrontal basal tumor resection, the frontal lobe was retracted subfrontally from the right side through an interhemispheric approach. Tumoral mass was dissected frontobasally from beneath the falx cerebri (E). After partial removal of the tumor, the falx was cut beneath the sinus to control the contralateral frontobasal portion (F). The cribriform plate was cauterized, crista galli was removed and drilled basally according to the presence or absence of invasion into dura and bone tissue at its insertion site after the tumor removal (G). Macroscopic view of tumour is seen (H). According to the size of the bone defect at the base of the tumor, reconstruction with pericranial flap and fibrin glue was performed (I).

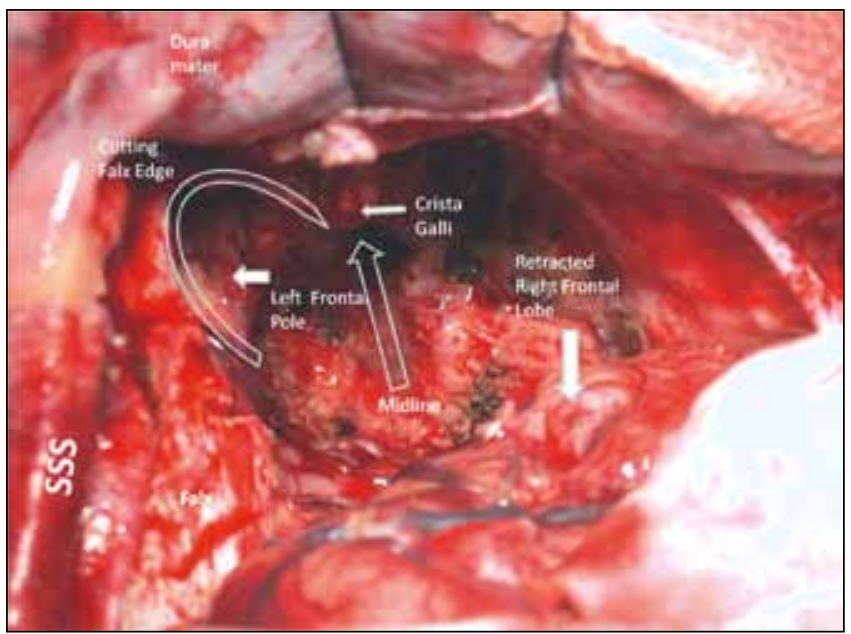

Figure 2: After removal of the tumor the retracted right frontal lobe, cut falx and left frontal lobe behind the cut falx and superior sagittal sinus (SSS) are seen. on each other. A paired sample test was used to evaluate the differences between the pre- and postoperative MMT, VIS and KPS. Significance was defined as a p value less than 0.05 .

\section{RESULTS}

The summary of clinical and radiological data is presented in Table I.

Age, headache, pre-operative VIS and KPS showed significant effects on pre-operative MMT $(p=0.041, p=0.040, p=0.012$, and $p<0.0001$, respectively). Age and pre-operative MMT significantly affected pre-operative VIS $(p=0.049$ and $p=0.012$, respectively). Pre-operative MMT significantly affected preoperative KPS ( $p=0.001)$ (Table III).

Growing pattern had no effect on pre- or postoperative MMT, VIS or KPS (Table II).

Tumor size affected pre-operative VIS $(p<0.0001)$ and KPS $(p=0.002)$. No effect was found on the post-operative results 

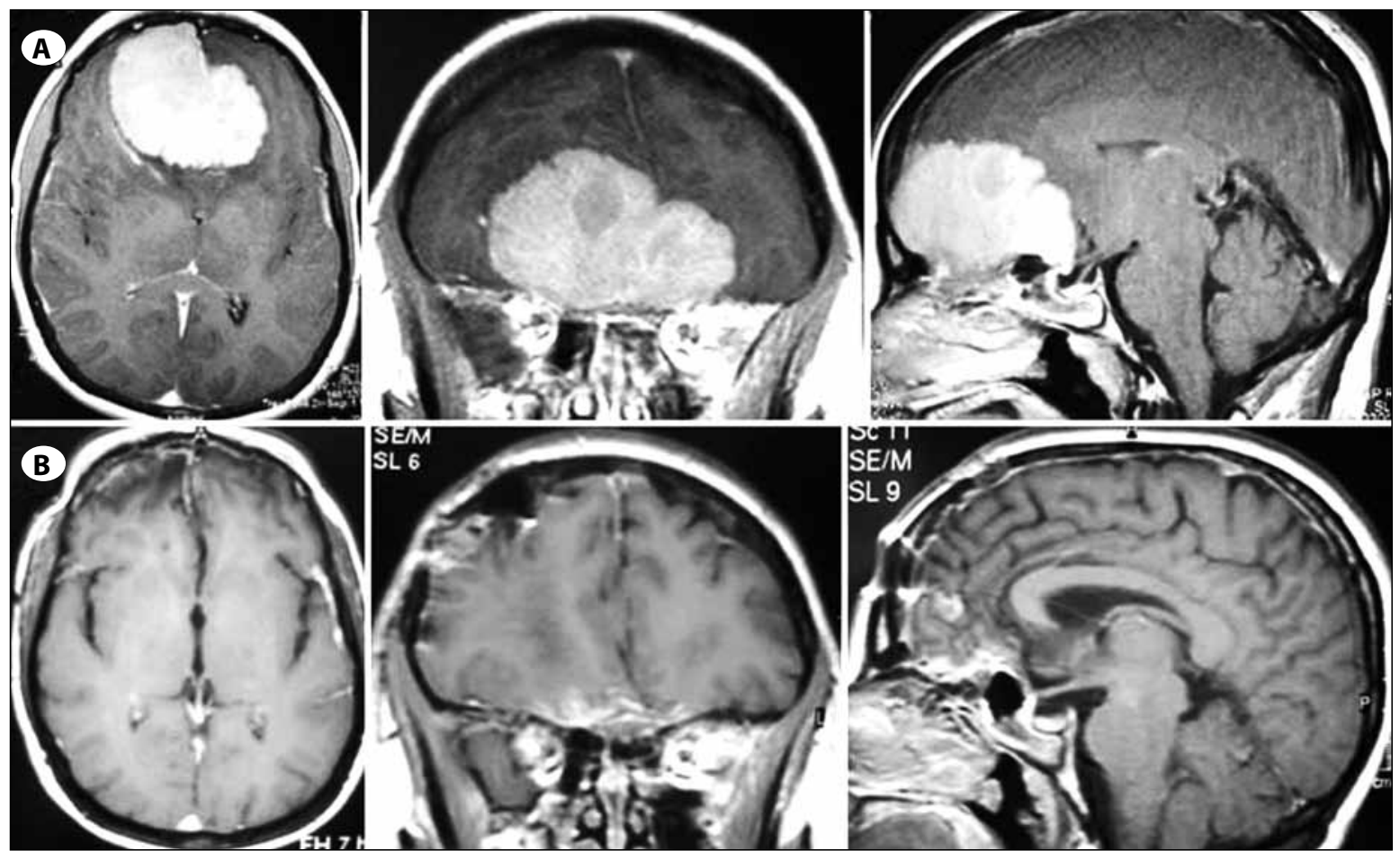

Figure 3: A) Preoperative T1-weighted axial (left), coronal (middle), and sagittal (right) views of MRI scan with gadolinium enhancement showing a large OGM. B) Late postoperative T1-weighted axial (left), coronal (middle), and sagittal (right) views of MRI scan with gadolinium enhancement 5 years after tumor removal through the right unilateral subfrontal interhemispheric transfalcial approach.
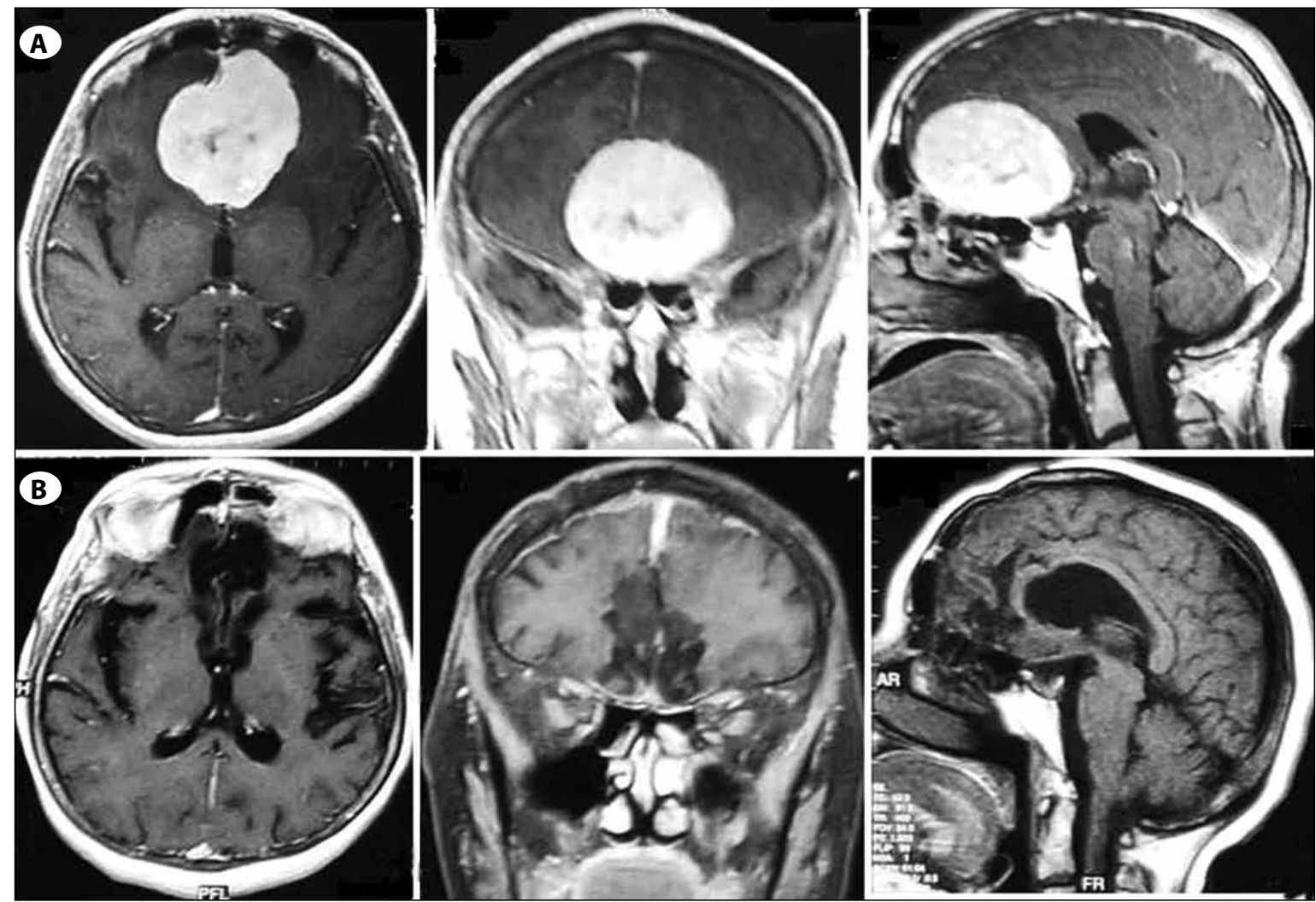

Figure 4: A) Preoperative T1-weighted axial (left), coronal (middle), and sagittal (right) views of MRI scan with gadolinium enhancement showing an OGM. B) Late postoperative T1-weighted axial (left), coronal (middle), and sagittal (right) views of MRI scan with gadolinium enhancement 8 years after tumor removal through the right unilateral subfrontal interhemispheric transfalcial approach. 
Table I: Summary of pre- and Post-Operative Clinical and Radiological Data Obtained in 42 Patients with Olfactory Groove Meningiomas and Their Comparisons (Significance was defined as a $p$ value less than 0.05).

\begin{tabular}{|c|c|c|c|}
\hline & Pre-operative & Post-operative & $\mathbf{p}$ \\
\hline \multicolumn{4}{|l|}{ Clinical data } \\
\hline Headache & $37(88 \%)$ & $18(42.8 \%)$ & $<0.0001$ \\
\hline Mental changes & $28(66.6 \%)$ & $11(26.2 \%)$ & $<0.0001$ \\
\hline Visual disturbance & $23(54.7 \%)$ & $4(9.5 \%)$ & $<0.0001$ \\
\hline Anosmia & 19 (45.2\%) & 35 (83.3 \%) & $<0.0001$ \\
\hline Epilepsy & $10(23.8 \%)$ & $12(28.5 \%)$ & 0.157 \\
\hline MMT & $22.78 \pm 3.23$ & $26.04 \pm 2.03$ & $<0.0001$ \\
\hline VIS & $4.59 \pm 8.44$ & $0.71 \pm 1.70$ & 0.001 \\
\hline KPS & $91.67 \pm 3.77$ & $92.14 \pm 8.12$ & 0.7 \\
\hline \multicolumn{4}{|l|}{ Tumor size } \\
\hline (Group 1) $<4 \mathrm{~cm}$ & $5(11.9 \%)$ & & \\
\hline (Group 2) $4-6 \mathrm{~cm}$ & $22(52.3 \%)$ & & \\
\hline$($ Group 3) $>6 \mathrm{~cm}$ & 15 (35.7\%) & & \\
\hline \multicolumn{4}{|c|}{ Growth pattern of the tumor } \\
\hline Midline & $26(62 \%)$ & & \\
\hline Right extension & $9(21.4 \%)$ & & \\
\hline Left extension & $7(16.6 \%)$ & & \\
\hline
\end{tabular}

(VIS, KPS and MMT), but the post-operative complication rate was affected by the size of the tumor $(p=0.025)$ (Table II).

No parameter showed any effect on post-operative KPS, as no significant difference was seen between pre- and post-operative KPS ( $p=0.7)$ (Table I, II). A significant positive difference was detected between pre- and post-operative MMT and VIS ( $p<0.0001$ and $p=0.001)$ (Table I).

There were no peri-operative deaths. When we evaluated complication rate with respect to tumor size, no complication with tumors was seen in group 1 . In group 2, epilepsy $(n=1$, $2.3 \%)$, meningitis $(n=1,2.3 \%)$, and frontal contusion $(n=1$, $2.3 \%)$ were observed. In group 3, CSF leak ( $n=2,4.7 \%)$, temporary diabetes insipidus $(n=1,2.3 \%)$, ACA infarction $(n=1,2.3 \%)$, frontal contusion $(n=1,2.3 \%)$, epilepsy $(n=1$, $2.3 \%)$, and intracerebral bleeding $(n=1,2.3 \%)$ were detected (Table III).

The patient with the ACA infarct was rendered dependent due to mental deterioration and mild paraparesis. One patient was re-operated upon in the early post-operative period due to hemorrhagic contusion of the right frontal lobe, causing hemiparesis and confusion. Clinical recovery was obtained, and the patient was discharged without any neurological deficit.

There was a significant positive difference between the pre- and post-operative headache incidences $(p<0.0001)$ and a negative difference in anosmia incidence $(p<0.0001)$. However, there was no difference between the pre- and postoperative seizure incidence $(p=0.157)$ (Table I).
Pre-operative median KPS was 91.67 (range, 90-100). Early post-operative median KPS was 92.14 (range, 60-100). The median follow-up score was 92.62 (range, 80-100). No parameters had any effect on post-operative KPS. There was no significant difference between the pre- and post-operative KPS $(p=0.7)$ (Table I).

Total excision of the tumor (Simpson Grade 1 or 2) was achieved in nearly all cases (97.6\%). No recurrence was seen in control MRls at the $6^{\text {th }}$ and $12^{\text {th }}$ postoperative months. The average follow-up duration was 52 months (range 16142 months). During follow-up, four patients died due to unrelated causes. Subtotal resection needed to be performed in one case due to invasion of the distal anterior cerebral and pericallosal arteries by the tumor. This case was re-operated upon four years later due to re-growth of the tumor, and subtotal resection was performed again.

\section{DISCUSSION}

OGM are a relatively infrequently type of intracranial meningioma (19). Several surgical approaches to olfactory groove meningiomas have been described (Table IV). Conventional approaches are frontal or bifrontal craniotomy with a subfrontal approach $(13,17,19,23,25,30)$, and a pterional approach is also used by many surgeons $(10,20,28)$. In cases where orbita and paranasal sinuses are exposed to tumoral invasion, craniofascial approaches can be used, which include frontal or bifrontal craniotomy combined with orbital and nasal osteotomies $(2,3,6,11,17,24)$.

There are two general principles of meningioma surgery. After the identification and cauterization of the nutrient 
Table II: The Evaluation of the Regression of the Parameters to the Pre- and Post-Operative VIS, MMT and KPS (Significance was defined as a $p$ value less than 0.05.). Increase in Pre-operative VIS had Significant Effect to Decrease in Pre-operative MMT and Increase in Post-operative VIS. Increase in Pre-operative KPS had Significant Effect to Increase in Pre-operative MMT. Increase in Tumor Size had Significant Effect to Increase in Pre-operative VIS and Decrease in Pre-operative KPS. Increase in Pre-operative MMT had Significant Effect to Increase in Post-operative MMT and Pre-operative KPS and Decrease in Pre-operative VIS

\begin{tabular}{|l|c|c|c|c|c|c|}
\hline Dependent variable & VIS-pre & VIS-post & MMT-pre & MMT-post & KPS-pre & KPS-post \\
\hline VIS-pre & - & 0.009 & 0.012 & 0.214 & 0.142 & 0.842 \\
\hline Anosmia-pre & 0.767 & 0.315 & 0.405 & 0.961 & 0.161 & 0.094 \\
\hline KPS-Pre & 0.142 & 0.691 & 0.001 & 0.383 & - & 0.821 \\
\hline KPS-Post & - & 0.072 & - & 0.947 & - & - \\
\hline Tm-Extension & 0.787 & 0.691 & 0.281 & 0.984 & 0.246 & 0.200 \\
\hline Tm-Size & $<0.000$ & 0.311 & 0.053 & 0.155 & 0.002 & 0.185 \\
\hline MMT-pre & 0.012 & 0.604 & - & $<0.000$ & 0.001 & 0.831
\end{tabular}

Table III: Operative Complications in 42 Patients with OGM

\begin{tabular}{|l|l|c|l|}
\hline Tumor Size & Complication & $n \%$ & Management \\
\hline $44 \mathrm{~cm}$ & - & - & - \\
\hline $4-6 \mathrm{~cm}$ & & & \\
& CSF Leak Meningitis & $1(2.3 \%)$ & Lumbar drain replacement, antibiotics \\
\hline & Frontal Contusion & $1(2.3 \%)$ & Conservative treatment \\
\hline & Epilepsy & $1(2.3 \%)$ & Proper antiepileptic medication \\
\hline & Frontal Contusion & $1(2.3 \%)$ & Conservative treatment \\
\hline & ACA infarct & $1(2.3 \%)$ & Patient dependent \\
\hline & Epilepsy & $1(2.3 \%)$ & Proper antiepileptic medication \\
& Intracerebral Bleeding & $1(2.3 \%)$ & Re-operated \\
\hline & Diabetes Insipidus & $1(2.3 \%)$ & Temporary \\
& CSF Leak & $2(4.7 \%)$ & Lumbar drain replacement, antibiotics \\
\hline & Total & $10(23.8 \%)$ & \\
\hline
\end{tabular}

arteries, the origin of the tumor should be identified and total resection can be performed.

Nutrient arteries of olfactory groove meningiomas usually arise from anterior and posterior ethmoidal, middle meningeal and ophthalmic arteries $(4,11,14)$. Identification and cauterization of these nutrient arteries were provided by starting from the anterior part of the tumor's basal portion in our unilateral approach. Earlier blockage of tumoral blood supply permits non-traumatic dissection of the frontal lobe and thus excellent visualization of ACAs, optic nerves and chiasm (14). With this approach, we obtained significantly better post-operative VIS than pre-operative VIS. Zevgaridis et al. reported similar results using bifrontal and frontal approaches (30). Nakamura et al. reported that $55 \%$ of their patients showed visual improvement; however, they used a frontolateral and bifrontal approach (16). Bassiouni reported an $83 \%$ improvement in visual acuity and $100 \%$ improvement in visual field using primarily a bifrontal and pterional approach (4).
These tumors usually displace the ACA postero-superiorly rather than encasing them. Therefore, preservation of the ACA was possible with the excellent visualization and dissection of the ACA, which was provided with the unilateral transfalcial approach in all but one case in this series.

OGM originate from cribriform plates and extend into the ethmoid sinus, nasal cavity and orbita $(2,6,17,19,21,22,24,26)$. After removal of the tumor, cribriform plates should be always scrutinized, and the remnants should be removed using ring curettes or cauterization. This intervention, which we consider important for preventing recurrence, might be achieved using any approach. Due to retraction of the frontal lobe, cauterization and curettage of the cribriform plate, olfaction impairment is seen in all series of OGM patients. However this important aspect is rarely investigated $(4,29)$. Protecting the anatomical continuity or destruction of the olfactory nerve and cribriform plate showed no post-operative difference in the sense of olfaction (4). Therefore, no attention was paid to protect olfactory nerve in our series, and extensive resection 
Table IV: Summary of Published Articles of OGM

\begin{tabular}{|c|c|c|c|c|}
\hline Series and year & Surgical approach & Number of cases & Tumor size (cm) & $\begin{array}{c}\text { Rate of total excision } \\
(\%)\end{array}$ \\
\hline Mayfrank and Gilsbach (14), 1996 & interhemisferic & 18 & $1.5-7.0$ & 100 \\
\hline Paterniti et al (20), 1999 & pterional & 20 & NA & 100 \\
\hline \multirow[t]{2}{*}{ Tsikoudas and Hirsch (26), 1999} & bifrontal & 13 & $<6$ (5 cases) & NA \\
\hline & & & $>6$ ( 8 cases $)$ & \\
\hline \multirow[t]{2}{*}{ Turazzi et al (28), 1999} & pterional & 37 & $<6$ (14 cases) & 100 \\
\hline & & & $>6$ ( 23 cases $)$ & \\
\hline Zevgaridis et al (30), 2001 & frontal & 5 & 6.7 & 100 \\
\hline Hentschel and DeMonte (11), 2003 & bifrontal biorbital & 13 & 5.6 & 85 \\
\hline \multirow[t]{3}{*}{ Tuna et al (27), 2005} & total & 25 & NA & 100 \\
\hline & bifrontal & 19 & & \\
\hline & pterional & 6 & & \\
\hline \multirow[t]{6}{*}{ Spektor et al (24), 2005} & total & 80 & 4.6 & 90 \\
\hline & bifrontal & 35 & & \\
\hline & pterional & 18 & & \\
\hline & subcranial & 11 & & \\
\hline & unifrontal & 9 & & \\
\hline & frontoorbital & 7 & & \\
\hline \multirow[t]{5}{*}{ Bassiouni et al (4), 2007} & total & 56 & 5.2 & 100 \\
\hline & bifrontal & 36 & & \\
\hline & pterional & 13 & & \\
\hline & unifrontal & 4 & & \\
\hline & frontoorbital & 3 & & \\
\hline \multirow[t]{3}{*}{ Nakamura et al (16), 2007} & bifrontal & 46 & 4.9 & 93.5 \\
\hline & frontolateral & 34 & 4.2 & 91.2 \\
\hline & pterional & 2 & NA & NA \\
\hline Present series & unilateral & 42 & 5.6 & 97.6 \\
\hline
\end{tabular}

was performed. However, due to unilateral retraction of the right frontal lobe, left olfactory nerve can be prevented with our approach, if it was not invaded by the tumor.

In this approach, cerebrospinal fluid can be drained through the interhemispheric cistern to achieve a larger anterior fossa exposure and thus relieve intracerebral pressure. Therefore, retraction of the frontal lobe would not be problematic, as assumed. In our study, no cases required frontal lobe resection for tumor excision. We performed partial lobectomy and duraplasty in only one case due to cerebral edema associated with hemorrhagic contusion during the early postoperative period. He was the first case on whom we operated with this technique. This complication usually results from retraction injury of the brain. Prevention of this complication might be easier than its treatment. One should remember that the brain should never be retracted more than $2 \mathrm{~cm}$ from the base of the skull. A better guideline is not to retract the brain more than what can be achieved with gravity. Adequate measures should be taken to reduce the intracranial pressure by the use of mannitol furosemide, hyperventilation, and CSF drainage before starting retraction of the brain. Drainage of CSF using lumbar spinal puncture was not a preventive measure we routinely used. After the occurrence of this complication, we employed all of these preventive measures to all of our cases preoperatively.

The bifrontal approach has been traditionally used for large tumors. Ligation of the superior sagittal sinus could impair venous drainage leading to problematic cerebral edema $(3,4,27)$. Retraction of both frontal lobes would result in potential venous congestion and edema. Because of these disadvantages, we thought that a unilateral frontal interhemispheric approach would meet all of our surgical principles and requirements. We performed a bilateral frontobasal approach in our clinic until 1996, and from 1996 on we have performed the unilateral frontal interhemispheric approach, starting from the right side regardless of the 
growth pattern and size of the tumor. Because of the slow growth pattern of these tumors, the initial clinical symptoms are usually related to the frontal lobe $(4,16,27)$. With a unilateral approach, the left frontal lobe was protected from surgical injury and the right frontal lobe was preserved from several injuries related to over-retraction. There are no studies evaluating the pre- and post-operative mental status of the patients quantitatively. Different ratios of improvement of mental functions are reported $(4,16,18,23,28)$. With the unilateral approach, our patients showed significant improvement in their MMT scores. No patient showed any impairment by MMT in the post-operative period in our series.

Nakamura et. al (16) compared pre- and post-operative KPS of the patients, which were operated on either frontolateral or bifrontal approach. Mean KPS's were 70 in both groups preoperatively. However it was 80 in frontolateral group and 75 in bifrontal group. The results were not compared statistically. Better outcome similar to our series in frontolateral approach can be due the retraction of one frontal lobe.

The pterional approach is the shortest way to reach the parasellar region $(10,28)$. The posterior pole of the tumor can be dissected and separated from the optic nerve and cerebral arteries earlier in the procedure. Turazzi et al. (28) demonstrated that this approach provides a shorter route to the tumor than a subfrontal approach. Venous compression due to retraction of the frontal lobes can be avoided. This takes less time than bifrontal craniotomy and avoids CSF leaks because the frontal sinus is not transected. Thus, opening of basal cisternas and drainage of CSF will decompress the brain, facilitating tumor resection. Although we have gained limited experience with this approach, we considered it difficult to master the dissection of the tumor from the basal aspect, coagulate the nutrient arteries, and achieve the dissection of the contralateral tumor. Difficulty in reaching tumor parts that have invaded paranasal sinuses through cribriform plates will always create a potential risk of recurrence. Therefore, we prefer the subfrontal approach.

Henscthel and DeMonte (11) classified olfactory groove meningiomas into two main groups, midline and paramidline. Some surgeons reported that they prefer to define the surgical approaches as pterional and subfrontal based on the localization of the tumor (27). Some other surgeons prefer to use either a pterional $(10,20,27)$, unilateral or bilateral subfrontal approach regardless of the localization of the tumor $(3,5,7,11,14,18,19,25)$. Al Mefty (2) and Babu et al. (3) combined orbital osteotomy with the unilateral frontal approach. They emphasized that this approach avoids bifrontal retraction and possible cognitive dysfunction. If there is an extensive paranasal sinus involvement, combined endoscopic (into the paranasal sinuses) and transcranial resection can be performed in the same session or staged. This can provide control of the tumor residue in nasal cavity.

Mayfrank described the unilateral frontal interhemispheric approach as anterior border of the craniotomy being located at the superior border of the frontal sinus (14). Gaining access to basal nutrient arteries through a transtumoral approach will lead to excessive blood loss. Because the frontal sinus is not opened, postoperative risk of CSF fistula and rhinorrhea are not an issue with this approach. In 37 cases out of 42 in our series, the frontal sinus was opened. No cases presented with complications of rhinorrhea or infection.

Nakamura et al. (16) reported that via a frontolateral approach, they made a $2 \times 2.5-\mathrm{cm}$ craniotomy incision between the lateral rim of frontal sinus and orbital button, opened the Sylvian fissure to drain CSF and thus relieved the cerebral pressure with minimal frontal lobe retraction. They extracted through such a narrow opening larger tumors, up to $8 \mathrm{~cm}$ in the longest dimension, without any serious complication. In their series of 82 cases, they reported that a frontolateral approach led to relatively lesser morbidity and mortality than a bifrontal approach. The results of tumor removal via the frontolateral approach were very good, but a longer followup period is necessary to evaluate long-term tumor control.

OGM are benign tumors. Nowadays, using modern microsurgical techniques, complete excision can be accomplished with minimal morbidity. The incidence of morbidity from a unilateral interhemispheric transfalcial approach is low. The results of the unilateral approach also are within an acceptable range when compared with those of previously reported series, but long-term follow-up is certainly needed to confirm these results because recurrence rates in the long term are reportedly higher $(15,17)$.

\section{CONCLUSION}

The unilateral interhemispheric approach can be preferred due to its sparing of superior sagittal sinus, minimal retraction of the contralateral frontal lobe, provision of an adequate operating field for frontobasal dissection, and preservation of the optic nerve, chiasm and vascular structures posterior to the tumoral mass. With the preservation and decompression of the optic nerve and chiasm improvement on the visual functions can be achieved with this modified approach. Left olfactory nerve can be preserved if it was not invaded by the tumor. Due to prevention of the left frontal lobe from any retraction and adequate decompression of the both frontal lobes, protection or improvement can be achieved in the cognitive functions post-operatively.

\section{REFERENCES}

1. Al-Mefty O, Holoubi A, Rifai A, Fox JL: Microsurgical removal of suprasellar meningiomas. Neurosurgery 16: 364-372, 1985

2. Al-Mefty O: Tuberculum sellae and olfactory groove meningioma, in Sekhar LN, Janecka IP (eds): Surgery of Cranial Base Tumors. New York: Raven Press, 1993: 507-519

3. Babu R, Barton A, Kasoff SS: Resection of olfactory groove meningiomas: Technical note revisited. Surg Neurol 44: 567-572, 1995

4. Bassiouni H, AsgariS, Stolke D: Olfactory Groove meningiomas: Functional outcome in a series treted mirosurgically. Acta Neurochir (Wien) 149:109-121, 2007 
5. Cushing $\mathrm{H}$, Eisenhardt $\mathrm{L}$ : The olfactory meningiomas with primary anosmia, in Cushing $\mathrm{H}$, Eisenhardt $\mathrm{L}$ (eds): Meningiomas. Springfield: Charles C. Thomas, 1938: 250-282, 1938

6. Delashaw JB Jr, Jane JA, Kassell NF, Luce C: Supraorbital craniotomy by fracture of the anterior orbital roof. Technical note. J Neurosurg 79: 615-618, 1993

7. El Gindi S: Olfactory groove meningioma: Surgical techniques and pitfalls. Surg Neurol 54: 415-417, 2000

8. Fahlbusch $\mathrm{R}$, Schott $\mathrm{W}$ : Pterional surgery of meningiomas of the tuberculum sellae and planum sphenoidale: Surgical results with special consideration of ophthalmological and endocrinological outcomes. J Neurosurg 96(2):235-243, 2002

9. Folstein MF, Folstein SE, McHugh PR: Mini-mental state. A practical method for grading the cognitive state of patients for the clinician. J of Psychiat Res 12(3):189-198, 1975

10. Hassler W, Zentner J: Surgical treatment of olfactory groove meningiomas using the pterional approach. Acta Neurochir Suppl (Wien) 53:14-18, 1991

11. Hentschel SJ, DeMonte F: Olfactory Groove meningiomas. Neurosurg Focus 14(6):4, 2003

12. Karnofsky DA, Burchenal JH: The Clinical Evaluation of Chemotherapeutic Agents in Cancer. In: MacLeod CM (Ed), Evaluation of Chemotherapeutic Agents, Columbia: Univ Press, 1949:196

13. Long DM: Meningiomas of the olfactory groove and anterior fossa, in: Atlas of Operative Neurosurgical Technique: Cranial Operations. vol. 1, Baltimore: Williams \& Wilkins, 1989: 238-241

14. Mayfrank L, Gilsbach JM: Interhemispheric approach for microsurgical removal of olfactory groove meningiomas. $\mathrm{Br}$ J Neurosurg 10: 541-545, 1996

15. Mirimanoff RO, Dosoretz DE, Linggood RM, Ojemann RG, Martuza RL. Meningioma: Analysis of recurrence and progression following neurosurgical resection. J Neurosurg 62(1):18-24, 1985

16. Nakamura M, Struck M, Roser F, Vorkapic P, Samii M: Olfactory groove meningiomas: Clinical outcome and recurrence rates after tumor removal throught the frontolateral and bifrontal approach. Neurosurgery 60: 844-852, 2007

17. Obeid F, Al-Mefty O: Recurrence of olfactory groove meningiomas. Neurosurgery 53: 534-543, 2003
18. Ojeman RG: Supratentorial meningiomas: Clinical features and surgical management. In: Wilkins RH, Rengachary SS eds. Neurosurgery, vol 1. New York: McGraw-Hill, 1996:873-890

19. Ojemann RG: Olfactory groove meningiomas, in Al-Mefty O (ed): Meningiomas. New York: Raven Press, 1991:383-393

20. Paterniti S, Fiore P, Levite A, La Camara A, Cambria S: Basal meningiomas a retrospective study of 139 surgical cases. J Neurosurg Sci 43: 107-113,1999

21. Samii M, Ammirati M: Olfactory groove meningiomas, in Samii M ed: Surgery of the Skull Base: Meningiomas. Berlin: Springer Verlag, 1992:15-25

22. Sekhar LN, Nanda A, Sen CN, Snyderman CN, Janecka IP: The extended frontal approach to tumors of the anterior, middle, and posterior skull base. J Neurosurg 76:198-206, 1992

23. Solero $\mathrm{CL}$, Giombini S, Morello $\mathrm{G}$ : Suprasellar and olfactory meningiomas. Report on a series of 153 personal cases. Acta Neurochir (Wien) 67: 181-194, 1983

24. Spektor S, Valarezo J, Fliss DM, Gil Z, Cohen J, Goldman $J$, Umansky F: Olfactory groove meningiomas from neurosurgical and ear, nose, and throat perspectives: Approaches, techniques, and outcomes. Neurosurgery 57 (Suppl 4):268-280, 2005

25. Symon L, Rosenstein J: Surgical management of suprasellar meningioma. Part 1: The influence of tumor size, duration of symptoms, and microsurgery on surgical outcome in 101 consecutive cases. J Neurosurg 61: 633-641, 1984

26. Tsikoudas A, Martin-Hirsch DP: Olfactory groove meningiomas. Clin Otolaryngol Allied Sci 24: 507-509, 1999

27. Tuna $H$, Bozkurt $M$, Ayten $M$, Erdogan A, Deda H: Olfactory groove meningiomas. J Clin Neurosci 12: 664-668, 2005

28. Turazzi S, Cristofori L, Gambin R, Bricolo A: The pterional approach for the microsurgical removal of olfactory groove meningiomas. Neurosurgery 45: 821-826, 1999

29. Welge-Luessen A, Temmel A, Quint C, Moll B, Wolf S, Hummel $\mathrm{T}$ : Olfactory function in patients with olfactory groove meningioma. J Neurol Neurosurg Psychiatry 70(2): 218-221, 2001

30. Zevgaridis D, Medele RJ, Muller A, Hischa AC, Steiger HJ: Meningiomas of the sellar region presenting with visual impairment; impact of various prognostig fators on surgical outcome in 62 patients. Acta Neurochir 143: 471-476, 2001 